\title{
How Income Changes During Unemployment: Evidence from Tax Return Data*
}

\author{
Laura Kawano \\ Office of Tax Analysis \\ US Department of Treasury \\ Laura.Kawano@treasury.gov
}

\author{
Sara LaLumia \\ Department of Economics \\ Williams College \\ Sara.Lalumia@williams .edu
}

March 21, 2013

\begin{abstract}
This paper uses tax return data from 1999 to 2009 to provide new estimates of wage losses during unemployment, and to examine how other types of income change during an unemployment spell. Periods of unemployment are associated with significant reductions in wage income, equivalent to approximately $16 \%$ of pre-unemployment household-level earnings and 30\% of individual-level earnings. Households partially compensate for these wage losses in ways that vary across groups: Spousal earnings increase in the case of married couples, filers more likely to have accrued financial and housing wealth realize greater amounts of capital gains, and older filers take early withdrawals from restricted savings accounts. More generous UI benefits crowd out wage income of unemployed workers, but have mostly small or zero effect on spousal earnings and non-wage income.
\end{abstract}

\footnotetext{
*We are grateful for feedback from Jim Cilke, Dan Silverman, Mel Stephens, conference participants at the National Tax Association and Michigan Tax Invitational, and seminar participants at Williams College and the Office of Tax Analysis. The views expressed in this paper are those of the authors and do not necessarily reflect the policy of the US Department of Treasury.
} 
An important concern in recent policy debates is the experiences of the unemployed when they lose their jobs through no fault of their own. Understanding the costs of these spells of unemployment has been of central interest as the "Great Recession" has contributed to high rates of unemployment, even prompting recent expansions in unemployment insurance eligibility. Previous research has demonstrated that unemployment has an immediate negative impact on an individual's earnings, and evidence suggests that the labor market consequences can persist over the long run. These estimates of the wage losses associated with job loss have relied on administrative data from state unemployment offices (e.g. Jacobson, LaLonde and Sullivan 1993, Couch and Placzek 2010), on retrospective survey data from the Displaced Worker Survey (e.g. Farber 1997), or on longitudinal data from surveys such as the PSID (e.g. Stevens 1997)

In this paper, we utilize a previously unexplored source of data - individual tax returns to provide new evidence on the magnitude of earnings losses associated with unemployment. We construct a panel of income tax returns, spanning 1999 to 2009, for households who have evidence of an unemployment spell. To examine the experiences of these households surrounding unemployment, we estimate fixed effects regressions that compare income amounts in years with unemployment insurance (UI) benefit receipt to income amounts in other years. We estimate changes in wage income through an unemployment spell, and consider how these changes are influenced by the generosity of a state's unemployment insurance system. In addition, we explore the extent to which households use income sources other than wages to smooth consumption through an unemployment spell.

Tax return data provide some important advantages relative to other data sources widely used to investigate the income changes associated with unemployment. First, tax returns contain information on many different types of income. This allows us to investigate a variety of compensatory behaviors that individuals may use in the face of declining wage income. In particular, we analyze realized capital gains, net proceeds from sales of stock, and penalties associated with early withdrawals from restricted savings accounts. Second, wage income as 
measured on tax returns is likely more accurate than wage income reported in other datasets. Survey respondents may provide inaccurate recollections of previous earnings, and this problem may be exacerbated when earnings are fluctuating over time due to unemployment. ${ }^{1}$ In contrast, wage income on a tax return is verified by third-party information returns, the W-2 forms that employers file on behalf of their employees. Previous research relying on administrative data from unemployment insurance programs has been restricted to studying income earned within one state or within a small set of states. ${ }^{2}$ In contrast, all wage income is included on the tax return, regardless of the state in which it is earned. Third, by linking tax returns and supporting documentation filed with the IRS, we are able to observe both individual-level earnings and household-level measures of other income types. This allows us to analyze within-household behavior in response to one spouse's experience of unemployment. Finally, we have access to a relatively long panel, following taxpayers from 1999 to 2009. This allows us to control for factors observed in pre-unemployment years, and to investigate the dynamics of behavior leading up to and following an unemployment spell.

We find that unemployment spells are associated with substantial declines in householdand individual-level wage income, equivalent to about $16 \%$ of pre-unemployment household earnings and about $30 \%$ of pre-unemployment individual earnings. The magnitude of this effect is within the range of job displacement effects estimated in survey and UI administrative data. Among married couples, we find that husbands increase their earnings to compensate for wage losses experienced by their unemployed wives, making up more than half of the wage loss on average. In contrast, wives' earnings change very little in response to husbands' unemployment. Consistent with a large prior literature showing that more generous UI benefits lengthen unemployment spells, we find that more generous UI programs crowd out wage income. Increasing the dollar amount of the state-level maximum weekly UI benefit amount by $1 \%$ is associated with about a $0.1 \%$ reduction in annual household-level

\footnotetext{
${ }^{1}$ Using a survey of workers laid off by a single company, Oyer (2004) finds that respondents recall a job paying about $5 \%$ more per year, on average, than it actually did.

${ }^{2}$ Jacobson et al. (1993) use data from Pennsylvania, Schoeni and Dardia (1996) analyze California workers, and Couch and Placzek (2010) study workers in Connecticut.
} 
wage income. This effect operates through crowd-out of individual-level wage income, with no evidence that the generosity of UI benefits crowds out spousal earnings.

We document that unemployment spells are associated with increases in aggregate nonwage income and in several of its components. This effect is concentrated among older households and homeowners, suggesting that non-wage income is utilized by those households who have accumulated some wealth from which to draw down income. Older households take larger amounts of penalized early withdrawals from restricted savings accounts. Capital gains and proceeds from equity sales increase for the full sample, and, sensibly, this response is concentrated among those who reported some equity-based income prior to unemployment. Our results suggest that more generous UI benefits have little effect on these changes in non-wage income.

\section{Previous Evidence on Unemployment and Income}

Much has been written about how job loss affects earnings, consumption, saving, and other behaviors. This section provides a brief overview of the literature on how households respond to unemployment spells, and on how the generosity of UI influences these responses.

Estimates of unemployment-related earnings losses have focused on a particular group, displaced workers. Although the precise definition can vary, Kletzer (1998) characterizes displaced workers as individuals with an established history of labor force attachment, who have lost jobs for structural reasons such as plant closures or layoffs, and who are unlikely to return to their pre-unemployment jobs. An early and influential estimate of wage losses for displaced workers is Jacobson et al. (1993). They use administrative data from the Pennsylvania UI program to track individual earnings over the years 1974 to 1986 . They find that displacement is associated with wage losses equal to about $25 \%$ of annual earnings, and that wage losses are persistent for several years after displacement. Couch and Placzek (2010) update and expand this analysis, using 1993-2004 administrative data from Connecticut. 
They find somewhat smaller wage impacts, with long-run annual wage losses of around 15\%. Other analyses that rely on data from state UI administrative records include Schoeni and Dardia (1996) with estimates of the long-run wage loss associated with unemployment ranging from $17 \%$ to $25 \%$, and Kodrzycki (2007) finding long-run losses of $11 \%$ to $14 \%$.

Estimates relying on survey data from the Displaced Worker Supplement (DWS) to the Current Population Survey have tended to produce somewhat smaller values, suggesting that job loss is associated with a ten to fifteen percent decline in wage income (Farber 1997). In an effort to reconcile the estimates from different sources, von Wachter, Handwerker and Hildreth (2008) match DWS and administrative data for workers in California. They find that the survey data suffer from recall errors, and that the larger estimates from administrative data are more reliable. Other estimates have relied on longitudinal surveys. Stevens (1997) uses data from the PSID, estimating long-run wage losses of 9\%. Estimates for younger workers included in the National Longitudinal Survey of Youth are 9\% for men and $12.5 \%$ for women (Kletzer and Fairlie 2003). To the best of our knowledge, our paper is the first to use tax return data to derive estimates of the wage losses associated with unemployment.

Consumption declines during unemployment spells, but by less than income. Stephens (2001) uses PSID data to compare the year before and the year after job displacements. He finds that earnings of the displaced household head fall by $25 \%$, family income falls by $13 \%$, and food consumption falls by only $5 \%$. Using both PSID and Consumer Expenditure Survey data, Dynarski and Gruber (1997) estimate that each dollar of earnings lost as a result of unemployment reduces consumption by about 10 cents.

Helping households to smooth consumption over an unemployment spell is one intention of the UI program. A strong inverse relationship between UI generosity and the drop in consumption at the time of unemployment indicates that UI programs are in fact helping households to smooth consumption. Alternatively, a weak relationship between UI generosity and changes in consumption indicates that self-insurance is largely adequate, and that UI mostly crowds out private consumption-smoothing mechanisms. Gruber (1997) finds substantial 
consumption-smoothing benefits of UI. He estimates that a 10 percentage point increase in the UI replacement rate (the weekly UI benefit amount divided by pre-unemployment weekly earnings) reduces the decline in food consumption by $2.65 \%$. Other estimates suggest much weaker average relationships between UI generosity and the decline in consumption at unemployment entry in Canada (Browning and Crossley 2001) and the United Kingdom (Bloemen and Stancanelli 2005). These papers highlight pre-unemployment wealth as an important correlate of heterogeneity in consumption responses. Among households with little liquid or financial wealth, more generous UI benefits permit greater consumption smoothing. Among wealthier households, more generous UI benefits have little benefit in terms of consumption smoothing.

Gruber (2001) documents substantial heterogeneity in the wealth held by the unemployed. Using SIPP data covering years 1984 to 1992, he finds that the median worker holds financial assets (not including housing wealth) sufficient to cover two-thirds of the unemploymentrelated income loss. One-third of workers have assets worth less than $10 \%$ of the income loss associated with unemployment, and approximately $17 \%$ of those entering unemployment spells have zero gross financial wealth. Gruber also finds that when state UI benefits are more generous, the unemployed draw down their gross financial wealth by a smaller amount. For every 10 percentage point increase in the UI replacement rate, the change in wealth during unemployment is $7.9 \%$ less negative. ${ }^{3}$

Other authors have used longer panels with alternative wealth measures to estimate the draw-down of savings during unemployment. Amromin and Smith (2003) consider how a variety of shocks, including job loss, influence the probability of taking penalized early withdrawals from retirement accounts. They use a panel of tax return data spanning 1987 to 1996. Among owners of IRAs, job loss is associated with a one percentage point increase in

\footnotetext{
${ }^{3}$ There is closely related research that considers the effect of UI generosity on the accumulation of savings. If forward-looking individuals anticipate relying on UI during a potential future unemployment spell, they may engage in less precautionary saving under a more generous UI system. Engen and Gruber (2001) use SIPP data to show that increasing the UI replacement rate by $10 \%$ would lower the average household's asset-to-income ratio by 0.16 percentage points, or by $2.8 \%$. Love (2006) finds that more generous UI crowds out 401(k) contributions of younger workers.
} 
the probability of taking a penalized IRA distribution. This is actually a large effect, as only $3.8 \%$ of IRA owners take a penalized withdrawal annually. Among households who receive any distribution from an employer-sponsored retirement plan, either a rollover to another account or a penalized early withdrawal, job loss is associated with a 4 percentage point increase in the probability of an early withdrawal. Housing wealth makes up a large share of the typical household's portfolio, and Hurst and Stafford (2004) consider how homeowners access that wealth through refinancing. Using PSID data on those who were homeowners continuously between 1989 and 1996, they find that an unemployment spell increases the probability of refinancing by 8 percentage points, or $25 \%$.

The behavioral effect of UI that has received the most attention is its effect on unemployment duration. Models of job search during unemployment generate the prediction that receiving more generous UI reduces search effort, and hence lowers the probability of exiting from unemployment. There is a very large empirical literature establishing that in fact more generous UI programs increase the duration of unemployment spells. Reviews of this literature are provided by Atkinson (1987) and Krueger and Meyer (2002). A typical estimate of the elasticity of unemployment duration with respect to UI benefit generosity is 0.8 (Meyer 1990), and estimates from more recent time periods are 0.5 to 0.6 (Chetty 2008, Kroft and Notowidigdo 2011). Naturally, when unemployment duration is longer the income losses associated with unemployment will be larger. ${ }^{4}$ Although we cannot observe the length of an unemployment spell in our tax return data, we use information on the size of the wage loss to make inferences about unemployment duration.

\section{Data}

We construct a panel of tax return data spanning years 1999 to 2009. Our data come from the Continuous Work History Sample (CWHS), collected by the Statistics of Income (SOI)

\footnotetext{
${ }^{4}$ This effect could be mitigated if longer time spent searching for a job eventually produces a higherquality match, but evidence suggests that the wage gains from longer search times are minimal (Addison and Blackburn 2000).
} 
division of the Internal Revenue Service, which contains a purely random sample of taxpayers based on the last four digits of social security numbers. We make several restrictions to our sample. First, because we are examining how responses to unemployment vary by the generosity of state unemployment benefits, we exclude tax filers who do not file in one of the 50 states or Washington D.C. We exclude returns filed by dependents and by those whose marital status is widow or "other." We restrict the age of the primary filer to be greater than 25 and less than $60 .^{5}$ After these restrictions, we have a sample of 442,685 returns, representing 66,291 distinct primary tax filers.

We make use of income data from Form 1040 including adjusted gross income (AGI) and several of its components, such as wages and salaries, business (Schedule C) income, capital gains realizations, and unemployment compensation. In addition, we collect data on income from the sale of equity from Schedule D of Form 1040. All monetary values are converted to real 2008 dollars using the CPI. Demographic data available on the 1040 include marital status and number of children living at home. The SOI data have been matched to Social Security Administration records, allowing us to observe date of birth and gender of primary and secondary filers. ${ }^{6}$

To separate household wage and salary income between primary and secondary filers, we use information from W-2 forms filed by employers. Because an individual can receive multiple $\mathrm{W}-2 \mathrm{~s}$ in a given year, we sum over all W-2s for each person in each year. As a check of data quality, we compare wages and salaries that are reported on 1040s and that are derived from W-2s. For approximately $92 \%$ of the observations, the difference between wages reported on the 1040 and wages derived from W-2 filings is no more than $\$ 25 .^{7}$ For

\footnotetext{
${ }^{5}$ Our choice of 60 as an upper bound on age reduces the possibility that individuals in our sample are making adjustments to their preferred retirement age in response to an unemployment spell. Chan and Stevens (2001) find that workers displaced in their 50s have about a $75 \%$ of returning to work in the two years after job loss, while workers displaced in their 60s return to work at even lower rates.

${ }^{6}$ Birth year and gender are sometimes missing. In addition, for a small percentage of the filers, birth year or gender may be coded differently for the same person between tax years, likely due to transcription error. In these instances, we assume that the modal response in the 11 year period is the correct one. There remain a small number of tax filing units for which we cannot derive an age of the primary or secondary filer. In these instances, we omit the tax filer from our analysis.

${ }^{7}$ There are several reasons why the wage and salary amount reported on a filer's 1040 can differ from
} 
all tax filers not married filing jointly, we define wage income as the larger of the 1040-based amount and the sum of W-2 amounts. For tax filers who are married filing jointly, we assign individual wages according to W-2 records, and split any positive difference between 1040 earnings and combined W-2 earnings equally between the primary and secondary filers.

There are other types of income that may be particularly relevant to unemployed individuals, but that are not reported on tax returns. Adverse labor demand shocks are associated with increased applications for Social Security Disability Insurance (DI) benefits (Autor and Duggan 2003), but DI income is not taxable and does not appear on the 1040 or on any associated information return. Informal transfers from family members increase during unemployment spells (Schoeni 2002, Bentolila and Ichino 2008). Only transfers above the annual exclusion amount (\$13,000 as of 2009) would trigger a gift tax liability, and this tax is the responsibility of the giver rather than the recipient. It is possible that job losers turn to under-the-table employment during a spell of UI receipt. There is little incentive for individuals to report this income to the IRS, and relatively high costs of discovering the true amount of such income via audits. We cannot study any of these types of income.

\subsection{Measuring Unemployment in Tax Return Data}

A tax return includes no direct measure of a person's unemployment status. UI income is observable, as it has been fully taxable since 1987 . We rely on this information to define an unemployment spell as a period in which UI income is received. This introduces differences between the sample of UI recipients we analyze and the full population of unemployed individuals. First, not all unemployed individuals are eligible for UI. Benefits are available to eligible workers who lose their jobs through no fault of their own, but not to those who are fired or quit. The self-employed are generally not eligible, and federal government employees are covered by a separate program. For wage workers, UI eligibility depends on whether pre-

W-2 wages. The 1040 amount will be larger if the individual received scholarship or fellowship income, tip income, certain employer-provided adoption benefits, or excess salary deferrals. The W-2 amount will be larger if the individual is a statutory employee with business-related expenses to deduct. These individuals report W-2 amounts on Schedule C, not on the wage line of the 1040. 
unemployment earnings are above state-specific thresholds. Ebenstein and Stange (2010) report that, over the years 1989 to 2006, $47 \%$ of unemployed individuals were eligible for UI. Second, not all individuals eligible for UI choose to take up the program. After declining over the 1980s, take-up rates among eligible individuals have increased moderately and are now approximately 80\% (Ebenstein and Stange 2010). Take-up is strongly related to the after-tax value of benefits (Anderson and Meyer 1997). While the set of UI recipients is smaller than the set of all unemployed individuals, it is a closer match to the group of displaced workers who have been the focus of much of the previous literature estimating wage losses associated with unemployment.

Unemployment compensation reported on Form 1040 represents the combined benefits received by all individuals included in the filing unit. To distinguish unemployment spells of primary filers from those of other members of the tax unit, we supplement the tax return data with information returns for primary and secondary filers. Information on individualspecific unemployment compensation comes from IRS Form 1099-G, where box 1 of the form contains unemployment compensation amounts of at least $\$ 10$. Because there can be many records for an individual in a year, we sum over 1099-G forms to construct a total unemployment compensation amount for each person and year combination.

To check the quality of the unemployment data, we compare the unemployment status that would be attributed to the tax filing unit based on Form 1040 with the unemployment status based on 1099-G filings. Approximately 90\% of observations in the panel have no unemployment compensation reported on the 1040 and no 1099-G UI income. About 8\% report unemployment compensation on the 1040 and have a corresponding 1099-G. About $2 \%$ of observations have a 1099-G showing receipt of UI income, but no unemployment compensation is reported on the $1040 .^{8}$ We characterize a filing unit as having experienced

\footnotetext{
${ }^{8}$ We suspect these are mainly cases of taxpayer confusion, in which individuals do not realize at the time of filing that UI payments must be reported on the 1040. This could happen if, at the time of filing, a taxpayer has forgotten that she received UI benefits. Comparisons of data from multiple sources show that many unemployment spells, particularly short spells, are unreported in survey data (Mathiowetz and Duncan 1988) and that only about $70 \%$ of aggregate dollars spent on UI are reported in several large-scale surveys (Meyer, Mok and Sullivan 2009). Even if a taxpayer accurately recalls her UI benefit receipt, she
} 
unemployment if UI compensation appears on either the 1040 or a 1099-G. We have checked the robustness of our results to other sample definitions.

Tax return data indicate the annual amount of UI benefits received, but include no information on the duration or timing of benefit receipt. We define the start of an unemployment spell for a tax filing unit as the tax year in which unemployment compensation is reported on either a 1099-G or 1040, conditional on no unemployment compensation reported in the year prior. Based on this definition, approximately $29 \%$ of tax filing units in our sample $(19,333$ of 66,291 ) enters an unemployment spell at some point over the course of the panel. We restrict attention to unemployment spells spanning at most two tax years. Over most of our sample period, UI benefits can be received for a maximum of 26 weeks. An individual who enters unemployment towards the end of the calendar year and receives 26 weeks of benefits will report UI compensation in two consecutive calendar years. There are individuals in our sample who report UI compensation in more than two consecutive years. These are likely cases of multiple unemployment spells, separated by periods of employment. We exclude unemployment spells that are reported in the first year that the tax filing unit appears in the sample because we cannot determine the year in which these spells began. After these restrictions, nearly $15 \%(9,749$ of 66,291$)$ of tax filing units in our sample enter an unemployment spell of two years or less. Of those who enter an unemployment spell, $74 \%$ of them enter only one spell; the maximum number of unemployment spells that any tax filing unit enters is four.

Figure 1 compares the annual unemployment rate, as computed by the Bureau of Labor Statistics, to the annual percentage of filing units in the CWHS sample that have UI income. The two series move together, with both increasing during recessions. The correlation of these two measures is 0.847 . There are several reasons why the levels of the two series differ. Each may not know these benefits are taxable. However, there are some situations in which a filer could have unemployment compensation reported on a 1099-G and legitimately report no UI income on the 1040. The recipient could have repaid all of the benefits he received during the year, or the individual may have received certain types of disability insurance payments that are reported on a 1099-G but not considered a substitute for UI. 
series has a different numerator (the number of unemployed individuals vs. the number of filing units receiving UI income) and a different denominator (the labor force vs. the number of filing units). Each also has a different time frame of reference. In the BLS data, an individual's unemployment status is determined by his activity in the week prior to the survey. If six percent of the labor force is unemployed in each month, with some churning of the particular individuals unemployed in any given month, the annual unemployment rate will be six percent. In the tax return data, UI receipt at any point during the year will cause a filing unit to be classified as unemployed in that year. If six percent of filing units receive UI in the first half of the year and a different six percent receive UI in the second half of the year, we will observe $12 \%$ of tax filing units reporting UI income. This explains why the rate of UI receipt in our tax sample is persistently higher than the BLS unemployment rate.

We use the state of residence reported on 1040s to match individuals with information on the benefit generosity of the UI system they face. ${ }^{9}$ UI recipients are paid a weekly benefit amount equal to some fraction, typically one half, of their pre-unemployment earnings, up to a cap. This cap, the maximum weekly benefit amount, varies widely across states and over time. During the period that we analyze, the maximum weekly benefit amount ranges from a low of $\$ 190$ (in Alabama in 1999-2001 and in Mississippi in 1999-2000) to a high of $\$ 628$ (in Massachusetts in 2009) ${ }^{10}$ As is standard in the UI literature, we use the maximum weekly benefit amount at the time of an individual's entry into unemployment as a summary measure of the benefit generosity he faces. We do not measure generosity as the maximum possible duration of unemployment benefit receipt, because most of the variation in potential duration is at the federal level and will be absorbed by year fixed effects.

\footnotetext{
${ }^{9}$ This introduces some measurement error. For an individual who lives and works in different states, the relevant UI program is the one corresponding to his state of employment.

${ }^{10}$ Details on state programs come from the semi-annual "Significant Provisions of State Unemployment Insurance Laws" published by the Department of Labor's Employment and Training Administration. Historical reports are available at http://www.ows.doleta.gov/unemploy/statelaws.asp. States can change their policies mid-year, and in cases where the January and July Department of Labor reports show different maximum benefit amounts, we use the simple average of the two. A small number of states offer a larger maximum weekly benefit amount for claimants with dependents. Results presented here use the benefit amount for a filer with no dependents, but we have checked that the patterns of results are robust to using the maximum weekly benefit amount including dependent allowances.
} 


\subsection{Descriptive Statistics}

Table 1 reports descriptive statistics for the two major samples we analyze in the remainder of the paper. The first column includes all observations for filing units observed entering into a period of UI receipt at least once over the years 1999 to 2009. There are 74,577 observations in this sample, covering 9,749 unique primary filers. Approximately half of these returns are jointly filed by married couples, and approximately $20 \%$ are filed by individuals with head of household filing status. It is reasonable to expect that UI recipients, who must have sufficient work history in order to be eligible for UI, likely have higher income and are older than are non-UI-receiving unemployed individuals. Averaging across all years, including years with UI receipt, the typical filing unit in our sample has household-level wage income of nearly $\$ 53,000$, has AGI of approximately $\$ 65,000$, and is headed by a primary filer who is 42 years old. More than 40\% appear to be homeowners, as measured by paying mortgage interest or deducting property taxes. Approximately $40 \%$ of returns in the sample report interest income, and approximately 12\% include realized income from capital gains. We interpret both of these variables as indicators of positive financial wealth. We construct a composite measure of non-wage income, summing all taxable income components on the 1040 other than wages and unemployment compensation, which we later use as a dependent variable. Table 1 shows that the mean amount of non-wage income is quite small, equal to $-\$ 1380$, and that there is substantial variation around this mean. Negative values reflect the inclusion of losses from business and from sales of depreciated assets.

The second column in Table 1 is restricted to filing units experiencing at least four years without UI receipt preceding the first observed receipt of UI. We will rely on this sample in wage loss equations that most closely match the Jacobson et al. (1993) specification. This group contains only about $20 \%$ as many observations as the full sample, but is quite similar to the full sample on observed characteristics. Both AGI and household-level wage income are approximately $\$ 5000$ higher in the restricted sample than in the full sample. 


\section{Estimation Strategy}

We are interested in estimating how earnings and other types of reported income change when a household experiences an unemployment spell, and in how a state's UI generosity influences these changes. Using the sample of households that experienced at least one unemployment spell over the course of our panel, we first estimate fixed effects regressions of the form:

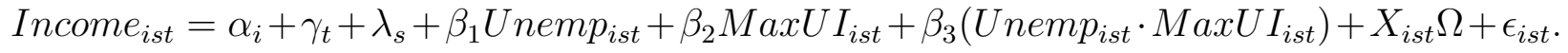

The dependent variable is the dollar value of a particular type of income reported by filing unit $i$ living in state $s$ in year $t$. In earnings regressions, the dependent variable is annual wage and salary income. The variable Unemp is a dummy equal to one in years with a spell of UI receipt and equal to zero otherwise. The coefficient on Unemp represents the change in income in a year of UI receipt relative to a filing unit's average income in all years with no UI receipt. The variable MaxUI measures the maximum weekly benefit amount an individual could receive. Most individuals living in the same state will have the same value of MaxUI in a given year. The exceptions are households in their second consecutive year of UI receipt. Benefit generosity is determined at the start of a spell, and remains constant over that spell. Thus, the second calendar year contained within a given unemployment spell has benefit generosity reflecting the rules in place in the previous calendar year. The interaction term Unemp $M a x U I$ allows us to estimate the extent to which more generous UI benefits affect the level of non-UI income reported during a spell of unemployment. A negative coefficient on this interaction indicates crowd-out: When UI benefits are more generous, a given type of income falls more during an unemployment spell. The vector $X$ includes timevarying characteristics: marital status, number of exemptions for children living at home, age and age squared of the primary filer, and dummies for several categories of lagged wage income. It also includes the annual state unemployment rate, as reported by the Bureau of 
Labor Statistics. The terms $\alpha_{i}, \gamma_{t}$, and $\lambda_{s}$ represent filing unit, year, and state fixed effects. Standard errors are clustered at the tax filing unit level.

Our estimation strategy makes use of variation over time within a filing unit. Equation 1 compares years in which a filing unit receives UI income to the pooled set of all years in which that same filing unit does not receive UI. Such an estimation strategy can yield biased estimates in the presence of long-run income trends. If wage income starts to decline prior to the start of an unemployment spell, or if wage income recovers only slowly after an unemployment spell, Equation 1 will understate the earnings loss associated with unemployment. Earlier studies show mixed evidence of pre-displacement declines in earnings, while consistently showing that wage recovery is slow. ${ }^{11}$

To allow for potential long-run adjustments in wage income, we estimate a second equation that includes dummies for the number of years elapsed since an unemployment spell:

Income $_{i s t}=\alpha_{i}+\gamma_{t}+\lambda_{s}+\sum_{k=-2}^{6}\left(\delta_{k} \cdot D_{i s t}^{k}\right)+\theta_{1} M a x U I_{s t}+\theta_{2}\left(U_{n e m p} p_{i s t} \cdot M a x U I_{s t}\right)+X_{i s t} \Omega+\epsilon_{i s t}$.

In this equation the dummy variables $D^{k}, k=-2, \ldots, 6$, indicate that an observation occurs $k$ years after a household's first observed receipt of UI income. Negative values indicate years prior to first UI receipt. The $D^{0}$ dummy is exactly equivalent to the Unemp dummy included in Equation 1. Without the MaxUI and Unemp.MaxUI terms, this equation closely matches a specification adopted by Jacobson et al. (1993) and widely used in the subsequent literature on wage losses during unemployment. We will estimate a version of Equation 2 without the MaxUI terms to benchmark our findings to the existing literature, but we are particularly interested in what can be learned about crowdout when the UI controls are included.

We estimate Equation 2 for a smaller sample, those for whom we observe at least four

\footnotetext{
${ }^{11}$ Jacobson et al. (1993) find that wage income starts to decline as early as three years before a job displacement associated with mass layoffs. The pre-displacement earnings decline is very small for those who lose jobs outside of mass layoffs, and subsequent estimates including Schoeni and Dardia (1996) and Couch and Placzek (2010) find no pre-displacement dip in earnings.
} 
years of data prior to first UI receipt. With this sample, and with the smallest value of $k$ equal to -2 , the estimates of $\delta_{k}$ can be interpreted as the change in wages $k$ years after entering unemployment, relative to wage income averaged over the third and fourth year prior to unemployment entry.

Our measure of earnings is annual wage and salary income as reported on the 1040 . The tax form reports wage income at the filing-unit level, but as described above we are able to use information from $\mathrm{W}-2$ forms to construct individual-level annual wage income. We consider both household- and individual-level earned income in our empirical analysis. Wage income is the dependent variable that allows the closest comparison to two strands of existing literature. First, we can compare existing estimates of the costs of job loss to our estimates of changes in annual wage income. Second, much of the literature investigating how unemployment insurance affects behavior has focused on the relationship between UI generosity and the length of unemployment spells. Making some assumptions about the stability of weekly earnings over time, we can convert unemployment duration elasticities from the literature into an imputed effect of UI generosity on annual wage income, which we then compare to our own estimates.

We are also interested in the extent to which individuals increase reliance on non-wage income during unemployment spells. We use several different measures of non-wage income as dependent variables. The first is a composite measure, the sum of all taxable income lines on the 1040 other than wages and UI benefits. About one quarter of the observations in our sample report any non-wage income. Next we consider two variables measuring income realized as a result of selling assets. We use the amount of taxable gains reported on the 1040, which aggregates long-term and short-term gains and losses, and which can take on either positive or negative values. ${ }^{12}$ Negative values occur when assets are sold at a loss. We also use the proceeds from all sales of equity, as reported on Schedule D. This

\footnotetext{
${ }^{12}$ This measure includes capital gains distributions paid out to holders of mutual fund shares. The choice of when to realize capital gains distributions from mutual funds is not within the control of the taxpayer, and thus it will not be a particularly easy margin along which to adjust during unemployment.
} 
variable is fully within the control of the taxpayer, and is always positive. The timing of capital gains realizations has been shown to be quite sensitive to tax treatment (Burman and Randolph 1994). Given that the maximum statutory rate on long-term capital gains fell from $20 \%$ to $15 \%$ in May 2003, we might expect to see a discrete change in capital gains realizations or in proceeds from equity sales partway through the panel. The inclusion of year fixed effects in our regression will account for any effect of this statutory rate change that was constant across states.

Finally, we are interested in whether people draw down balances held in savings accounts during unemployment spells. Tax return data do not include information on the stock of wealth held in savings accounts, but do include information on certain types of transactions. Withdrawals from traditional IRA accounts trigger a 10\% tax on the amount distributed, if the IRA holder is under age 59.5. ${ }^{13}$ Individuals who have held Roth IRAs for less than five years are subject to the same rules for early withdrawals as are holders of traditional IRAs, while those who set up a Roth IRA at least five years earlier are able to take tax-free withdrawals at any time. Withdrawals from an employer-sponsored retirement plan, most often a $401(\mathrm{k})$, are typically subject to the $10 \%$ tax if the account holder is under age 55 . We use a dependent variable which we refer to as the "retirement penalty," which combines the $10 \%$ tax paid on any penalized early withdrawal from an IRA or employer-sponsored retirement plan, as well as penalties paid on excess IRA contributions. We also consider the penalty paid on early withdrawals from certificates of deposit, which appears on the 1040 as an adjustment to taxable income.

When the dependent variable is one of our five measures of non-wage income, we present results from estimating Equation 1 only. This specification compares non-wage income reported in years of UI receipt to non-wage income reported in all other years combined. We have estimated Equation 2 for non-wage dependent variables, finding very little evidence

\footnotetext{
${ }^{13}$ There are a number of special cases under which an early IRA withdrawal is not subject to the $10 \%$ penalty. Withdrawals used for first-time home purchases or for qualified higher education expenses are exempt from the penalty. Most relevant for our analysis, withdrawals used to pay health insurance premiums are exempt for individuals who have lost their jobs.
} 
that non-wage income is adjusted in anticipation of or in the aftermath of an unemployment spell. To the extent that there is any non-wage income responsiveness at all, it is concurrent with UI receipt.

\section{Results}

\subsection{Wage Income}

Table 2 presents results from fixed-effects regressions describing how wage income changes during unemployment. Column 1 compares years of UI receipt to the full set of years without UI receipt. The dependent variable is annual household-level wage and salary income. As expected, wage income declines substantially in years with an unemployment spell. Consider a household facing the mean level of UI generosity, MaxUI $=\$ 363$. A year of UI receipt is associated with a change of $-3703-13.44(363)=-\$ 8582$ in annual wage income for this household. This is about $16 \%$ of average wage income in the year prior to unemployment $(\$ 52,052)$ or about $19 \%$ of average wage income in the first year of the sample $(\$ 45,976)$. The negative and significant coefficient on the Unemp $\cdot M a x U I$ term indicates that more generous UI benefits are associated with lower annual wage income in years involving UI receipt. In column 1 , raising the maximum weekly UI benefit amount by $\$ 1$ is associated with a $\$ 13.44$ decline in annual household-level wage income. To put this in context, the percentage change in annual wage income associated with a $1 \%$ increase in UI generosity is approximately equal to $\frac{-13.44 / 52052}{1 / 363}=-0.094 \%$. We obtain a similar estimate of the elasticity of annual wage income with respect to UI benefit generosity from a regression in which the dependent variable and UI benefit levels are measured in natural logs. This regression, not shown in Table 2, indicates an elasticity of $-0.105 .^{14}$

\footnotetext{
${ }^{14}$ The sample size is slightly smaller in this specification (72,103 filing unit-year observations for 9726 unique primary filers), as observations with zero wage income are dropped. Cases of zero wages are rare here relative to other analyses of unemployed individuals because the time period over which wages are measured is relatively long, a year rather than a quarter, and because we are considering combined wage income of all members of the filing unit. Repeating the level specification for the smaller sample with positive wage
} 
Column 2 estimates the same specification, with the dependent variable equal to individuallevel earnings of the household member who experiences unemployment. The sample size is smaller here, as we include only those individuals with at least four years of data prior to the first unemployment spell, to facilitate subsequent estimation of a specification with multiple leads and lags of unemployment entry. As was the case with household-level wage income, we find that unemployment is associated with a significant decline in individual-level wage income. We also find that more generous UI benefits crowd out annual individual-level earnings. Evaluated at the mean level of MaxUI for this sample, a year involving UI receipt is associated with a change of $-5179-12.51(373)=-\$ 9845$ in wage income. Each additional $\$ 1$ of MaxUI is associated with a $\$ 12.51$ decline in annual individual-level wage income. Given the mean value of individual wage income in the year prior to unemployment, $\$ 43,573$, the implied elasticity of annual wages with respect to UI benefit generosity is $\frac{-12.51 / 43,573}{1 / 373}=-0.107$.

There are numerous estimates in the literature of the extent to which greater generosity of UI benefits increases the duration of unemployment spells. Making some assumptions, these estimates can be converted to an implied effect on annual wage income, useful for checking whether our results are of plausible magnitude. Meyer (1990) estimates that a $10 \%$ increase in UI benefit generosity is associated with an $8 \%$ increase in unemployment duration. Individuals in his sample receive UI benefits for an average of 13 weeks, so an $8 \%$ increase in duration corresponds to roughly one additional week of unemployment. This is $1 / 52$, or $1.9 \%$, of the available time in a year. Assuming that wage income is spread evenly over the year, and that weekly wages are similar pre- and post-unemployment, this suggests that a $10 \%$ increase in UI benefit generosity would be associated with a $1.9 \%$ reduction in annual wage income. This is reasonably close to our estimate that a $10 \%$ increase in the maximum weekly benefit amount reduces annual individual-level wage income by about $1 \%$.

To this point, we have been comparing years of UI receipt to the full set of years without income yields results very similar to the column 1 level specification. 
UI receipt. Columns 3 and 4 of Table 2 present individual-level wage regression results including multiple leads and lags of entry into UI receipt. Referring back to Equation 2, these leads and lags correspond to the $D^{k}$ terms from $k=-2$ (indicating two years prior to unemployment entry) to $k=6$. Coefficients on the leads and lags can be interpreted as the difference in annual wage income relative to wage income averaged over the fourth and third year prior to first observed UI receipt. This specification allows us to test whether wage income begins to decline before UI receipt, and to allow for potentially slow wage recovery. Column 3 is the closest match to the analysis of Jacobson et al. (1993) while Column 4 adds UI generosity alone and interacted with the unemployment dummy. The $D^{k}$ coefficients reported in Table 2 are also shown graphically in Figure 2.

In contrast to Jacobson et al. (1993), we find that wage income is increasing in the years leading up to an unemployment spell. This is likely explained by the fact that our set of unemployed individuals is quite inclusive, rather than being restricted to workers leaving distressed firms carrying out mass layoffs. We find a large decline in wage income in the year that UI income is first received. In column 3, entry into UI receipt is associated with a wage decline of about $\$ 9350$, approximately $30 \%$ of individual pre-unemployment earnings. In column 4, evaluated at the mean level of UI generosity for this sample, $\$ 373$, the change in wage income is equal to $-4555-12.66(373)=-\$ 9277$. The decline in wage income is larger when UI benefits are more generous. When leads and lags of UI entry are included, each additional dollar of maximum weekly UI benefit is associated with a $\$ 12.66$ decline in annual wage income. Finally, columns 3 and 4 show that wages quickly recover to levels indistinguishable from the earliest pre-unemployment observations. By the first year after UI entry, wages are not statistically different from what they were three or four years prior to UI receipt. However, the wage gains accrued in the two years just prior to UI receipt are not made up until approximately five years later. The relatively fast wage recovery that we document may be partially explained by our use of a sample of UI recipients rather than a broader sample of unemployed individuals. Characteristics that are associated with UI 
eligibility (e.g. a recent record of persistent labor force attachment) and with UI take-up conditional on eligibility (e.g. willingness to complete paperwork) may also be associated with better post-unemployment labor market opportunities.

The pattern of coefficients on the demographic control variables is fairly stable across specifications. As expected, married households have substantially higher wage income than other households. Wage income is increasing with the age of the primary filer, at a decreasing rate. We include the annual state unemployment rate as a measure of general economic conditions, and find that it is negatively correlated with wage income, although the relationship is significant only when the dependent variable is household-level wage income.

Our data allow us to investigate heterogeneity in wage-earning behavior within the household. In particular, when the earnings of one spouse decline due to a spell of unemployment, the other spouse may increase his or her labor supply in an effort to compensate. This pattern has been referred to as the added worker effect. While most previous estimates of the added worker effect in the U.S. have been small (e.g. Lundberg 1985), evidence suggests that the effect is larger when UI benefits are less generous (Cullen and Gruber 2000) and when labor supply responses are measured over a longer time period (Stephens 2002).

We look for evidence of an added worker effect using data on individual-level wage income within married-couple households. In doing this analysis, we impose some additional sample restrictions. We look only at returns of couples who were married filing jointly in the year of entry into unemployment. ${ }^{15}$ We restrict the sample to filing units for which a 1099-G has been linked to the 1040, allowing us to identify which spouse experienced the unemployment spell. We exclude tax filing units where both the primary and secondary filers have received unemployment compensation at some point over the course of the panel.

The resulting analysis is shown in panel A of Table 3. The first column uses householdlevel wage income as the dependent variable, as in column 1 of Table 2, but imposes the

\footnotetext{
${ }^{15}$ Many filers in this sample experience a change in marital status over time. Only 2895 of the 3930 filing units included in Table 3 are married filing jointly in all observed years. Charles and Stephens (2004) present evidence that a job loss experienced by either a husband or wife, particularly if due to a layoff rather than a plant closing, is associated with an increased probability of divorce.
} 
new sample restrictions. The results for this subsample are similar to those for the full sample. Annual household-level wage income falls by almost $\$ 3900$ in years with UI receipt. The second column shows results for the wage income of the unemployed individual and the third column shows results for the wage income of his or her spouse. We find that the decline in household-level wage income is more than entirely explained by declines in the wage income of unemployed individuals themselves. Spousal wages do increase, although the change is not statistically different from zero. ${ }^{16}$ In column 4 we consider extensive margin labor supply responses. We construct a measure of employment equal to 1 if a person has any wage income at all during the year. We find no significant effect of UI receipt on a spouse's probability of employment. ${ }^{17}$

Next we consider whether more generous UI benefits have differential crowding-out effects on wage income of spouses. Column 1 of panel A shows that there is significant crowd-out of household-level wage income, and the remaining columns show that this effect occurs primarily through the earnings of the unemployed individual. Column 2 indicates that an additional dollar of maximum weekly UI benefits is associated with approximately a $\$ 12.50$ reduction in wage income of the unemployed individual. The negative coefficients in the spousal income regressions of columns 3 and 4, panel A, are consistent with more generous UI payments crowding out compensatory increases in spousal labor supply, but are not significantly different from zero.

The previous literature on the added worker effect has focused on the reactions of wives to their husbands' unemployment spells. We add to this literature by estimating both wives' responses to husbands' unemployment and husbands' responses to wives' unemployment. We find very different patterns of behavior for husbands and wives. Panel B of Table 3

\footnotetext{
${ }^{16}$ In results not reported in the table, we have defined a dependent variable equal to the sum of the spouse's wage income and net income from self-employment. It may be the case that some workers wish to increase labor supply during a spouse's unemployment spell, but are not afforded the flexibility to freely adjust hours. Earnings from self-employment are not subject to the same potential constraints imposed by an employer and may show more responsiveness to a spouse's unemployment. Empirically, including earnings from self-employment in the wage measure has very little effect on the results.

${ }^{17}$ The coefficient on the Unemp term in column 4 is multiplied by 100 for ease of interpretation.
} 
considers cases in which the husband experiences a spell of unemployment. A husband's unemployment spell is associated with a substantial decline in his own wage income but no significant change in his wife's wage income or in her probability of employment. This finding is largely consistent with previous estimates of near-zero contemporaneous added worker effects among wives. Turning to evidence on crowd-out, we find that raising the maximum weekly UI benefit by $\$ 1$ crowds out $\$ 17$ of an unemployed husband's annual wage income, but does not crowd out his wife's wage income.

In sharp contrast, panel $\mathrm{C}$ of Table 3 shows significant responses of husbands to wives' unemployment. The increase in earnings of husbands compensates for a large share of wives' lost earnings. When a wife enters unemployment, the average change in her own annual wage income is about $-\$ 6920$. Simultaneously, husbands' annual wage income increases by about $\$ 3920$. More generous UI benefits crowd out household-level wage income. The point estimates suggest a smaller degree of crowd-out for unemployed wives' earnings than for their husbands' earnings, although these coefficients are imprecise.

The observation that husbands increase their wage income by more than wives do during an episode of spousal unemployment is surprising, given the general pattern of small labor supply elasticities for married men. We offer several speculative explanations for this result. One possibility is that any individual is more likely to make adjustments to labor supply when that individual's spouse experiences a permanent, rather than temporary, job loss (Stephens 2002) and that wives' unemployment spells are more likely to be viewed as permanent. Unemployed women do have longer spells of unemployment than men, on average, and are more likely to end an unemployment spell by exiting the labor force (Ilg and Theodossiou 2012). A second possibility is that households in which wives are claiming unemployment benefits are less likely to contain young children, and thus involve fewer child care responsibilities that constrain the ability of either spouse to adjust labor supply. We cannot investigate this explanation directly, because we do not know the ages of children within the household. However, we do know that if a wife receives UI benefits, she must have 
had significant attachment to the labor force prior to unemployment. This would certainly be consistent with a lower probability of having pre-school-aged children in the household. Finally, Babcock and Laschever (2003) present evidence that women are less likely than men to negotiate for pay increases. It may be the case that a spouse's unemployment prompts some men to ask for a raise, but that few women respond in this way.

\subsection{Non-Wage Income}

Results for non-wage income are shown in Table 4. Non-wage income amounts are measured at the filing-unit level, and all filing units that are included in the household-level wage regressions are included in the non-wage regressions.

For four out of the five types of non-wage income we consider, there is evidence that households shift resources into years with unemployment spells, as shown by the positive and significant coefficients on the Unemp term. Spells of UI receipt are associated with significantly higher composite non-wage income, capital gains, proceeds from sales of equity, and penalties paid on early CD withdrawals. On average, non-wage income is $\$ 3400$ greater in years with UI receipt. Taken in context, this is a large increase. Averaging across all observations in our sample, including years with and without UI receipt, average non-wage income is $-\$ 1380$. Almost two-thirds of the increase in non-wage income is comprised of capital gains. Realizations of capital gains increase by more than $\$ 2100$ in years of unemployment. Penalties on early withdrawals from retirement accounts are higher during years with unemployment, although the difference relative to non-unemployment years is not statistically different from zero.

The coefficients on the Unemp - MaxUI term in Table 4 show little evidence that UI crowds out most types of non-wage income. Only in the case of penalties on early CD withdrawals is there any statistical evidence that more generous UI benefits induce crowd-out, and this effect is quite small in magnitude. Demographic controls are much less important in explaining non-wage income than in explaining wage income. 
The last row of Table 4 shows the percentage of observations reporting a particular type of income. The types of non-wage income that we analyze are reported relatively infrequently, with about a quarter of observations reporting any non-wage income and roughly $10 \%$ involving realized capital gains or proceeds from equity sales. Naturally, an individual cannot realize capital gains or proceeds from equity sales if he has no corresponding assets to sell. In the top portion of Table 5 we identify filing units that either realized net capital gains, reported income from selling equity, or received dividend income at some point between 1999 and their first observed UI receipt. Such individuals certainly held equities before entering unemployment. Within this group there are large and significant increases in capital gains in years of unemployment. On average, these filing units increase their net capital gains realizations by close to $\$ 7500$ in years with UI receipt. Gross proceeds from equity sales increase by approximately $\$ 44,000$. This coefficient is not quite significant at conventional levels, with a p-value of 0.103 . The coefficients on the interaction of UI generosity and an unemployment indicator are negative, consistent with more generous UI benefits crowding out the sale of assets. Increasing the maximum weekly UI benefit by $\$ 1$ is associated with an $\$ 18$ decline in annual net realized capital gains. As expected, patterns are very different among those with no equity-based income in the years leading up to unemployment. For these individuals, entering a spell of unemployment triggers essentially zero change in capital gains or equity sales. This is true regardless of the level of UI generosity.

A typical life-cycle model of savings behavior predicts low or even negative net wealth early in life, when individuals are most likely to be making costly investments in schooling and may be on particularly steep portions of the age-earnings profile. Older individuals, on average, will have built up larger stocks of wealth. Thus, the option to draw down assets during an unemployment spell may be more available to older individuals than to younger individuals. We divide our sample into older and younger cohorts, splitting the sample at the median age of primary filers as of the first year of data, corresponding to an age of 37 in 1999. The results are shown in the middle panel of Table 5. Among filing 
units headed by younger individuals, unemployment is not associated with a significant increase in the composite measure of non-wage income nor in any one of its components. For the older cohort, unemployment is associated with significantly larger amounts of nonwage income and with significantly greater penalized early withdrawals from retirement accounts and CDs. ${ }^{18}$ During unemployment, older filing units experience an average increase of almost $\$ 5000$ in aggregate non-wage income and report an additional $\$ 81$ in penalties on early retirement account withdrawals. Given the penalty rate of 10\%, this corresponds to withdrawing $\$ 810$ from IRA or $401(\mathrm{k})$ accounts. The greater non-wage income responsiveness of older households is not explained by more extreme wage losses for this group. When household-level wage regressions are estimated separately for the older and younger samples, the wage losses associated with unemployment are quite similar for the two groups. Entry into UI receipt is associated with an average wage decline of $\$ 3280$ for the younger sample and an average wage decline of $\$ 3875$ for the older sample.

Homeowners and renters may have different experiences during a spell of unemployment. On one hand, homeowners who have built up some equity have a valuable asset from which consumption value can be extracted via a home equity loan or refinancing (Hurst and Stafford 2004). If the propensity to become a homeowner is positively associated with an unobserved taste for saving, homeowners may also have greater levels of non-housing wealth that can be drawn down during unemployment. On the other hand, owning a home can strengthen one's ties to a particular geographic area and in turn make job search less effective. ${ }^{19}$ This would suggest that unemployment spells are associated with larger wage losses and potentially greater reliance on non-wage income for homeowners than for renters. We split our sample into likely homeowners and likely renters, classifying a primary filer as a likely homeowner if

\footnotetext{
${ }^{18}$ Our analysis does not condition on holding a retirement account or CD, mainly because ownership is not directly observed. In contrast, when Amromin and Smith (2003) consider IRA owners, they find a negative relationship between age and the probability of taking a penalized early distribution.

${ }^{19}$ Strong attachment of a homeowner to his particular locality's labor market is one explanation for the Oswald hypothesis, that higher rates of homeownership are associated with greater unemployment rates (Oswald 1996). This hypothesis has received support in cross-state U.S. data, particularly for middle-aged households (Green and Hendershott 2001), although analysis of individual-level PSID data fails to show that homeowners have longer unemployment duration than renters (Goss and Phillips 1997).
} 
he pays home mortgage interest or deducts property tax. ${ }^{20}$ In results not shown in Table 5, we have estimated wage regressions separately for the two groups. Likely homeowners do in fact experience substantially larger wage declines during unemployment, with a coefficient on Unemp of -7653 , relative to a coefficient of -2664 for likely renters. As shown in panel C of Table 5, we find significant increases in aggregate non-wage income during unemployment for both groups, with larger responses among the homeowners. Homeowners report an additional $\$ 5600$ in non-wage income in years of unemployment, while non-owners increase reported non-wage income by $\$ 1300$.

Browning and Crossley (2001) and Bloemen and Stancanelli (2005) show that the consumptionsmoothing benefits of unemployment insurance accrue mainly to households with limited financial wealth. A logical extension of these results is the prediction that UI is more likely to crowd out self-insurance mechanisms among higher-wealth households. The pattern of coefficients on the Unemp $\cdot$ MaxUI terms in Table 5 offers some suggestive evidence in line with this hypothesis, although the results are far from conclusive. Among households that are likely to have accumulated less wealth (younger vs. older households, and likely renters vs. likely owners), there is no evidence that more generous UI crowds out aggregate non-wage income or any of its components. For the older households, an additional $\$ 1$ of maximum weekly UI benefit is associated with a $\$ 7.79$ smaller increase in non-wage income during unemployment, with a p-value of 0.118 .

\section{Conclusions}

Unemployment imposes large financial strains on households. By providing comprehensive measures of income from wages and from non-wage sources, tax return data can offer new insight into how households cope with the strain of unemployment.

\footnotetext{
${ }^{20}$ We observe property tax payments on Schedule A, itemized deductions. We have two sources of information on mortgage interest paid: Schedule A and an information return, Form 1098, submitted by mortgage providers. This allows us to identify filing units that pay mortgage interest even if they do not itemize deductions.
} 
Using a panel of tax return data spanning 1999 to 2009, this paper first estimates the wage losses associated with unemployment. Our estimates are consistent with prior results from survey and administrative data, showing that unemployment is associated with annual wage income declines of about $16 \%$ when measured at the household level and about $30 \%$ when measured at the individual level. For married couples, the change in household-level wage income is more than fully explained by the wage income of the unemployed individual, with some compensatory increase in earnings of the spouse. While most of the prior literature on spousal responses has considered only wives responding to husbands' unemployment, our sample permits analysis of both husbands' and wives' unemployment spells. Perhaps surprisingly, we find that husbands increase their earnings substantially during wives' unemployment spells.

We find that households use capital income as a source of private insurance against negative income shocks. Aggregate non-wage income increases by about $\$ 3400$ during a spell of unemployment, nearly equal to the concurrent net decline in household-level wage income. We find significant increases in realized capital gains, concentrated among homeowners and among those who show evidence of holding equity prior to unemployment. We also find that households, particularly those headed by older individuals, are tapping into their retirement savings to smooth consumption through unemployment spells. This finding bears on the importance of the optimal treatment of retirement savings vehicles. The penalty on early distributions from these accounts is meant to discourage the use of such funds prior to retirement, but such penalties may be quite costly for those with a temporary decline in wage earnings.

Examining the ways that households cope with spells of unemployment is also important for evaluation of the unemployment insurance program. One concern about the UI program is that more generous benefits reduce job search effort of the unemployed. Consistent with the large literature showing that more generous UI benefits are associated with longer unemployment spells, we find that more generous benefits are associated with lower annual wage 
earnings. Across several specifications, we find that raising the maximum weekly UI benefit amount by $\$ 1$ crowds out about $\$ 13$ of annual wage income. We also investigate whether more generous UI benefits crowd out non-wage income. Overall, we find little evidence of this type of crowd-out. The amount by which aggregate non-wage income, realized capital gains, and early withdrawals from restricted savings accounts change during unemployment is generally insensitive to the level of UI benefits. These findings should be reassuring for policy-makers evaluating recent increases in UI generosity.

\section{References}

Addison, John T. and McKinley L. Blackburn, "The Effects of Unemployment Insurance on Postunemployment Earnings," Labour Economics, 2000, 7 (1), 21-53.

Amromin, Gene and Paul Smith, "What Explains Early Withdrawals from Retirement Accounts? Evidence from a Panel of Taxpayers," National Tax Journal, 2003, 56 (3), $595-612$.

Anderson, Patricia and Bruce Meyer, "Unemployment Insurance Take-Up Rates and the After-Tax Value of Benefits," Quarterly Journal of Economics, 1997, 112, 913-937.

Atkinson, A. B., "Income Maintenance and Social Insurance," in Alan J. Auerbach and Martin Feldstein, eds., Handbook of Public Economics, Elsevier, 1987, pp. 780-908.

Autor, David H. and Mark G. Duggan, "The Rise in the Disability Rolls and the Decline in Unemployment," Quarterly Journal of Economics, 2003, 118 (1), 157-206.

Babcock, Linda and Sara Laschever, Women Don't Ask: Negotiation and the Gender Divide 2003.

Bentolila, Samuel and Andrea Ichino, "Unemployment and Consumption Near and Far Away from the Mediterranean," Journal of Population Economics, 2008, 21 (2), 255-280.

Bloemen, Hans G. and Elena G. F. Stancanelli, "Financial Wealth, Consumption Smoothing and Income Shocks Arising From Job Loss," Economica, 2005, 72, 431-452.

Browning, Martin and Thomas F. Crossley, "Unemployment Insurance Benefit Levels and Consumption Changes," Journal of Public Economics, 2001, 80 (1), 1-23.

Burman, Leonard E. and William C. Randolph, "Measuring Permanent Responses to Capital-Gains Tax Changes in Panel Data," American Economic Review, 1994, 84 (4), $794-809$. 
Chan, Sewin and Ann Huff Stevens, "Job Loss and Employment Patterns of Older Workers," Journal of Labor Economics, 2001, 19 (2), 484-521.

Charles, Kerwin Kofi and Melvin Stephens, "Job Displacement, Disability, and Divorce," Journal of Labor Economics, 2004, 22 (2), 489-522.

Chetty, Raj, "Moral Hazard versus Liquidity and Optimal Unemployment Insurance," Journal of Political Economy, 2008, 116 (2), 173-234.

Couch, Kenneth A. and Dana W. Placzek, "Earnings Losses of Displaced Workers Revisited," American Economic Review, 2010, 100 (1), 572-589.

Cullen, Julie Berry and Jonathan Gruber, "Does Unemployment Insurance Crowd Out Spousal Labor Supply?," Journal of Labor Economics, 2000, 18 (3), 546-572.

Dynarski, Susan and Jonathan Gruber, "Can Families Smooth Variable Earnings?," Brookings Papers on Economic Activity, 1997, 1, 229-303.

Ebenstein, Avraham and Kevin Stange, "Does Inconvenience Explain Low Take-Up? Evidence from Unemployment Insurance," Journal of Policy Analysis and Management, 2010, 29 (1), 111-136.

Engen, Eric M. and Jonathan Gruber, "Unemployment Insurance and Precautionary Saving," Journal of Monetary Economics, 2001, 47 (3), 545-579.

Farber, Henry S., "The Changing Face of Job Loss in the United States, 1981-1995," Brookings Papers on Economic Activity, Microeconomics, 1997, 1997, 55-128.

Goss, Ernest P. and Joseph M. Phillips, "The Impact of Home Ownership on the Duration of Unemployment," Review of Regional Studies, 1997, 27 (1), 9-27.

Green, Richard K. and Patric H. Hendershott, "Home-ownership and Unemployment in the US," Urban Studies, 2001, 38 (9), 1509-1520.

Gruber, Jonathan, "The Consumption Smoothing Benefits of Unemployment Insurance," American Economic Review, 1997, 87 (1), 192-205.

_ , "The Wealth of the Unemployed," Industrial and Labor Relations Review, 2001, 55 (1), 79-94.

Hurst, Erik and Frank Stafford, "Home is Where the Equity Is: Mortgage Refinancing and Household Consumption," Journal of Money, Credit, and Banking, 2004, 36 (6), 985-1014.

Ilg, Randy E. and Eleni Theodossiou, "Job Search of the Unemployed by Duration of Unemployment," Monthly Labor Review, 2012, 135 (3), 41-49.

Jacobson, Louis S., Robert J. LaLonde, and Daniel G. Sullivan, "Earnings Losses of Displaced Workers," American Economic Review, 1993, 83 (4), 685-709. 
Kletzer, Lori G., "Job Displacement," Journal of Economic Perspectives, 1998, 12 (1), $115-136$.

and Robert W. Fairlie, "The Long-Term Costs of Job Displacement for Young Adult Workers," Industrial and Labor Relations Review, 2003, 56 (4), 682-698.

Kodrzycki, Yolanda K., "Using Unexpected Recalls to Examine the Long-Term Earnings Effects of Job Displacement," Federal Reserve Bank of Boston Working Paper 2007.

Kroft, Kory and Matthew J. Notowidigdo, "Should Unemployment Insurance Vary with the Unemployment Rate? Theory and Evidence," Working Paper 2011.

Krueger, Alan B. and Bruce D. Meyer, "Labor Supply Effects of Social Insurance," in Alan J. Auerbach and Martin Feldstein, eds., Handbook of Public Economics, Elsevier, 2002, pp. 2327-2392.

Love, David, "Buffer Stock Saving in Retirement Accounts," Journal of Monetary Economics, 2006, 53 (7), 1473-1492.

Lundberg, Shelly, "The Added Worker Effect," Journal of Labor Economics, 1985, 3 (1, part 1), 11-37.

Mathiowetz, Nancy A. and Greg J. Duncan, "Out of Work, Out of Mind: Response Errors in Retrospective Reports of Unemployment," Journal of Business and Economic Statistics, 1988, 6 (2), 221-229.

Meyer, Bruce D., "Unemployment Insurance and Unemployment Spells," Econometrica, 1990, 58 (4), 757-782.

, Wallace K. C. Mok, and James X Sullivan, "The Under-Reporting of Transfers in Household Surveys: Its Nature and Consequences," NBER Working Paper 15181 2009 .

Oswald, Andrew J., "A Conjecture on the Explanation for High Unemployment in the Industrialized Nations: Part I," Mimeo, University of Warwick 1996.

Oyer, Paul, "Recall Bias Among Displaced Workers," Economics Letters, 2004, 82 (3), 397-402.

Schoeni, Robert, "Does Unemployment Insurance Displace Familial Assistance?," Public Choice, 2002, 110 (1-2), 99-119.

Schoeni, Robert F. and Michael Dardia, "Wage Losses of Displaced Workers in the 1990s," RAND Working Paper 1996.

Stephens, Melvin Jr., "The Long-Run Consumption Effects of Earnings Shocks," Review of Economics and Statistics, 2001, 83 (1), 28-36.

_ - "Worker Displacement and the Added Worker Effect," Journal of Labor Economics, 2002, $20(3), 504-537$. 
Stevens, Ann Huff, "Persistent Effects of Job Displacement: The Importance of Multiple Job Losses," Journal of Labor Economics, 1997, 15 (1, part 1), 165-188.

von Wachter, Till M., Elizabeth Weber Handwerker, and Andrew K. G. Hildreth, "Estimating the 'True' Cost of Job Loss: Evidence using Matched Data from California 1991-2000," Working Paper 2008. 
Figure 1: Comparison of Unemployment Rate and UI Recipiency Rate

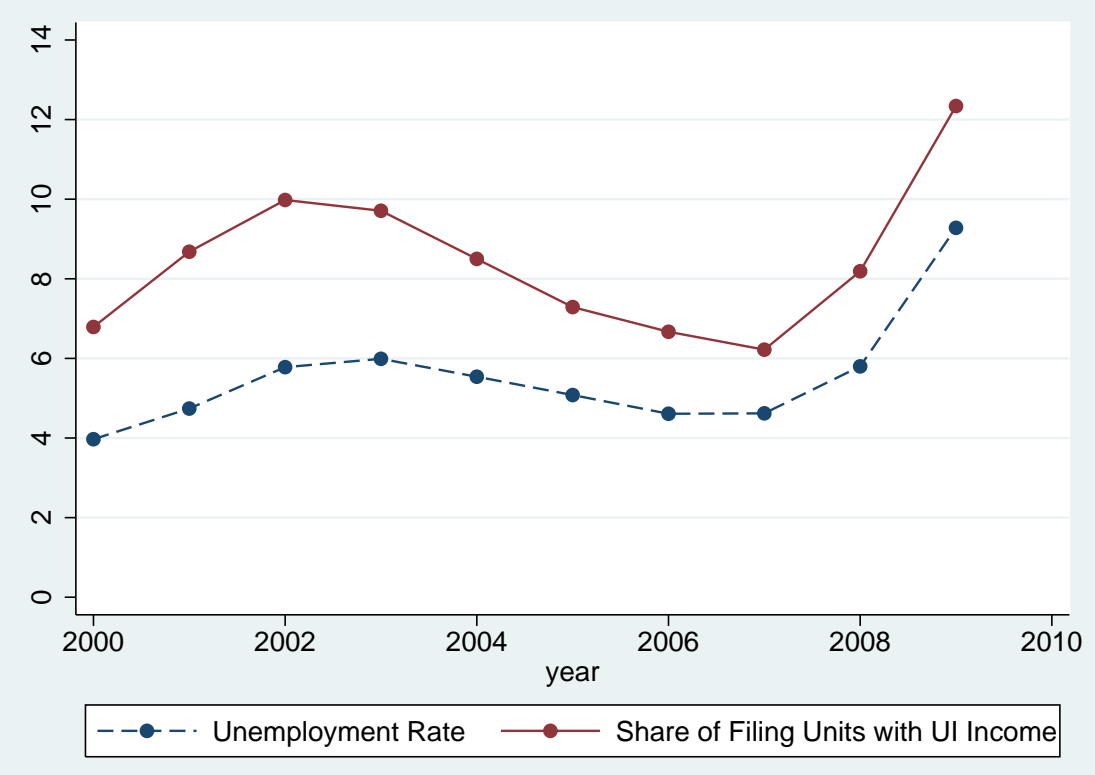

The dotted line indicates the national unemployment rate, as reported by the Bureau of Labor Statistics. The solid line indicates the percentage of tax returns in the sample that report any income from unemployment insurance benefits. 
Figure 2: Coefficients from Wage Regressions

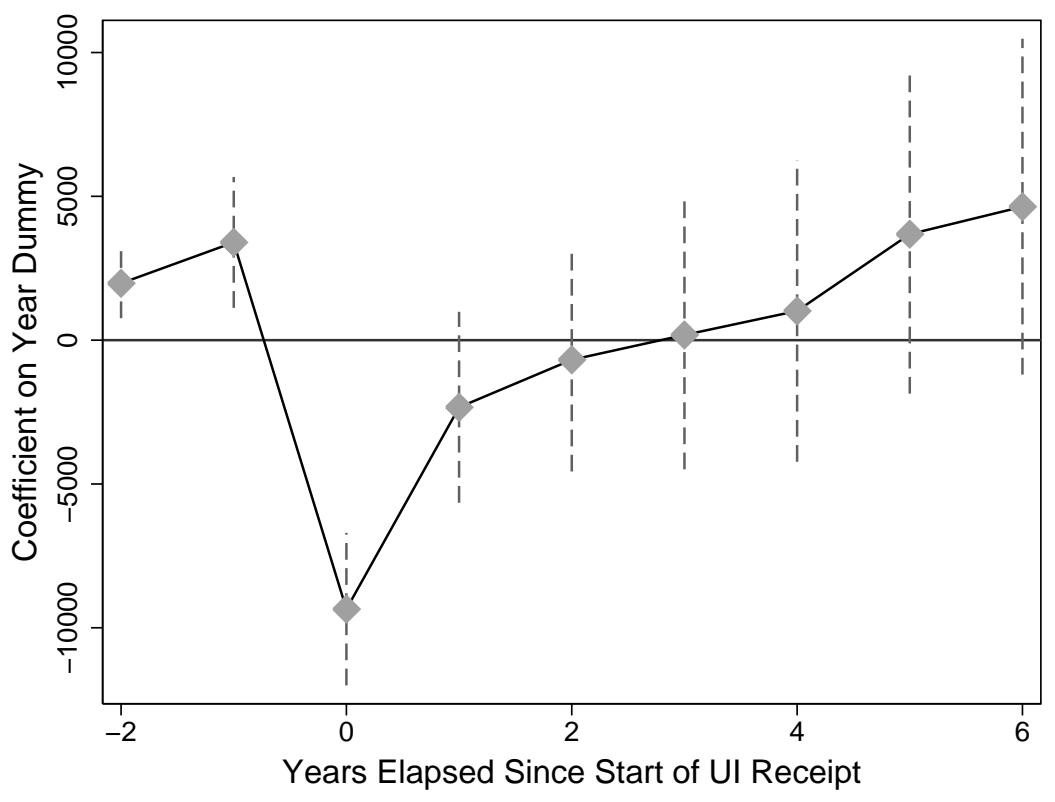

(a) Regression with no UI Controls

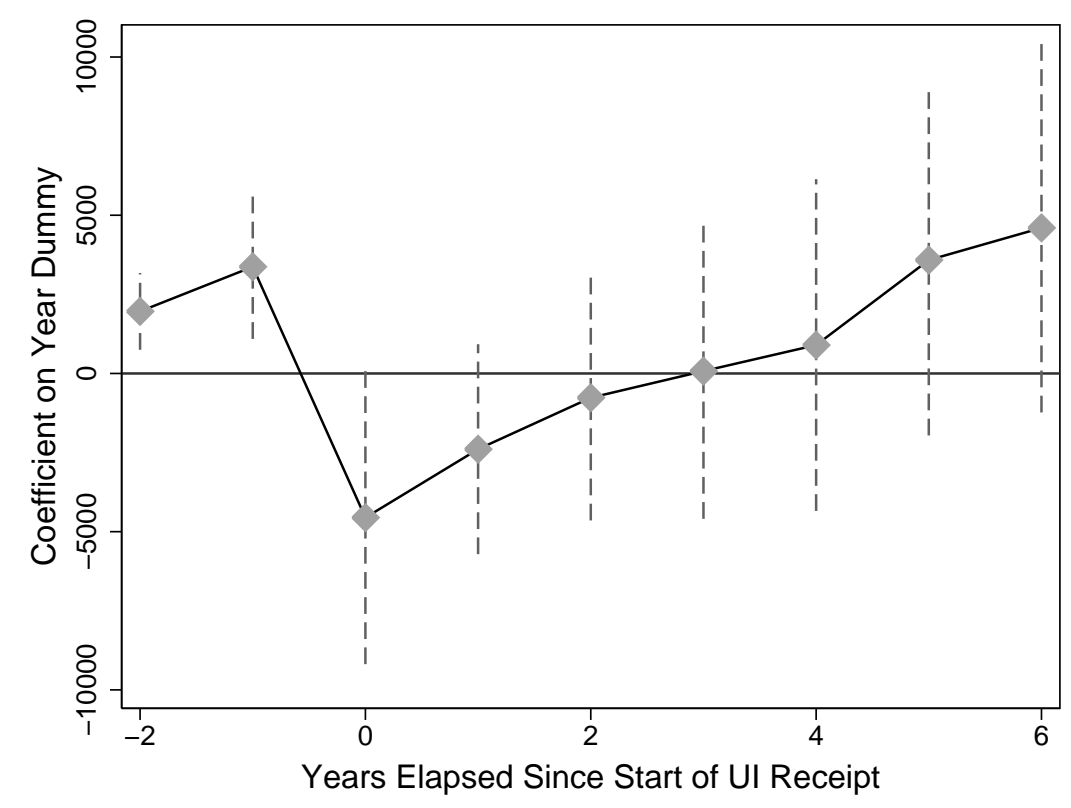

(b) Regression with UI Controls

Each figure plots the regression coefficients and $95 \%$ confidence intervals on a series of dummy variables, $D^{k}$, for number of years elapsed since entry into unemployment. The dependent variable is annual wage income. The regression summarized in the top panel includes no controls for UI generosity. The regression summarized in the bottom panel controls for the maximum weekly benefit amount, in levels and interacted with the $D^{0}$ dummy. 
Table 1: Summary Statistics

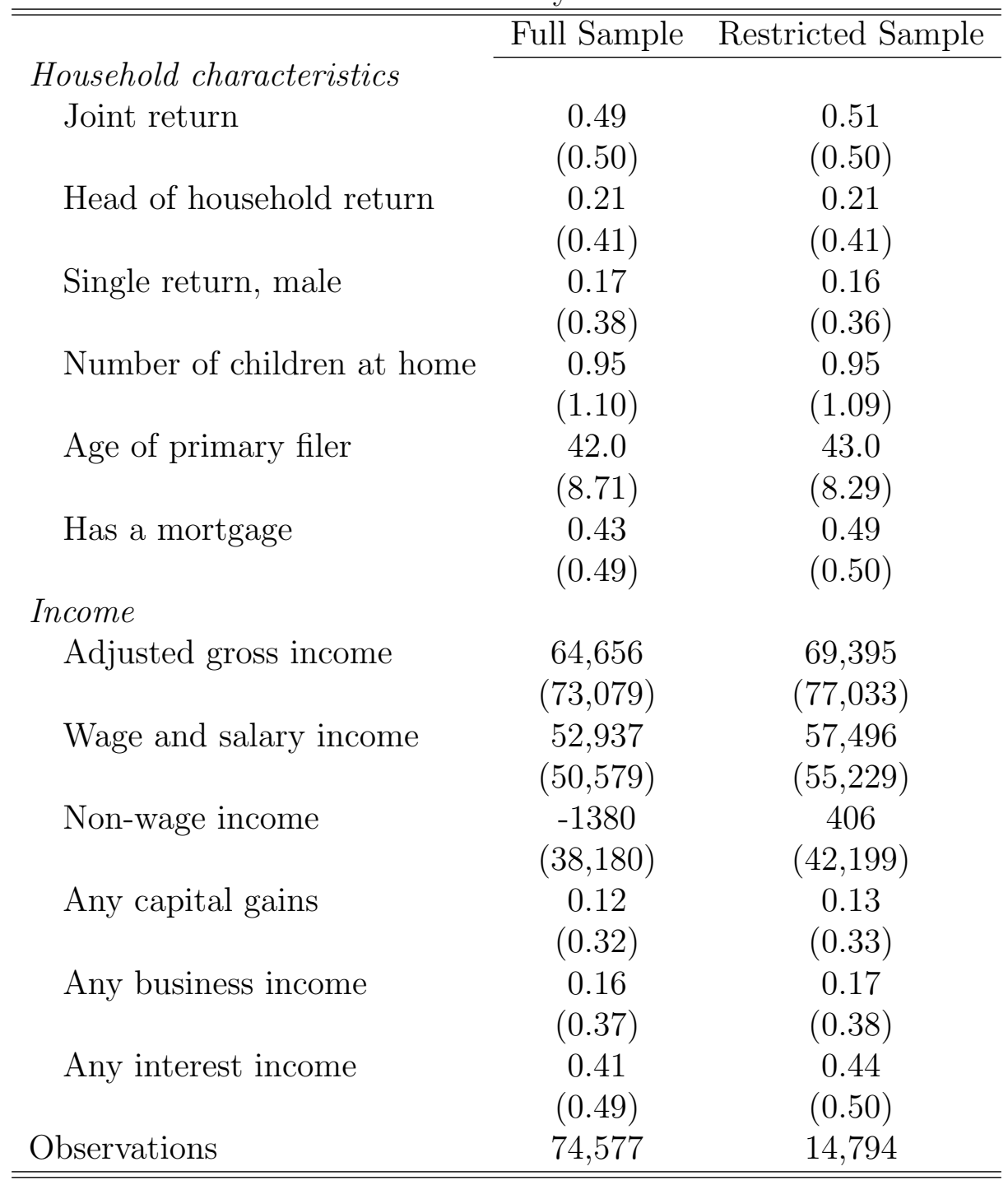

The table reports sample means with standard deviations in parentheses. The restricted sample includes only filing units for which we observe at least four consecutive years with no UI receipt prior to the first UI receipt. 
Table 2: Fixed Effects Regression Results, Wage Income

\begin{tabular}{|c|c|c|c|c|}
\hline \multirow[b]{2}{*}{ Unemp } & $\begin{array}{l}\text { Household } \\
\text { Wages } \\
(1)\end{array}$ & $(2)$ & $\begin{array}{l}\text { dividual Wag } \\
\text { With Lead } \\
\text { (3) }\end{array}$ & $\begin{array}{l}\text { and Lags } \\
(4)\end{array}$ \\
\hline & $\begin{array}{c}-3702.59^{* * *} \\
(969.35)\end{array}$ & $\begin{array}{l}-5179.24^{* *} \\
(2063.26)\end{array}$ & $\begin{array}{l}-9351.67^{* * *} \\
(1351.38)\end{array}$ & $\begin{array}{l}-4555.61^{*} \\
(2361.59)\end{array}$ \\
\hline Unemp · MaxUI & $\begin{array}{c}-13.44^{* * *} \\
(2.79)\end{array}$ & $\begin{array}{c}-12.51^{* *} \\
(5.82)\end{array}$ & & $\begin{array}{c}-12.66^{* *} \\
(5.80)\end{array}$ \\
\hline MaxUI & $\begin{array}{l}13.31^{* * * *} \\
(4.92)\end{array}$ & $\begin{array}{c}-2.12 \\
(11.11)\end{array}$ & & $\begin{array}{c}-2.66 \\
(11.16)\end{array}$ \\
\hline Married & $\begin{array}{c}24786.01^{* * *} \\
(740.26)\end{array}$ & $\begin{array}{l}9286.90^{* * *} \\
(1372.88)\end{array}$ & $\begin{array}{l}9550.63^{* * *} \\
(1388.94)\end{array}$ & $\begin{array}{l}9558.04^{* * *} \\
(1385.33)\end{array}$ \\
\hline Children at home & $\begin{array}{c}11.99 \\
(251.18)\end{array}$ & $\begin{array}{c}-66.09 \\
(442.73)\end{array}$ & $\begin{array}{c}-53.09 \\
(443.92)\end{array}$ & $\begin{array}{c}-51.81 \\
(444.08)\end{array}$ \\
\hline Age of primary & $\begin{array}{l}3459.52^{* * *} \\
(276.14)\end{array}$ & $\begin{array}{l}2351.58^{* * *} \\
(751.34)\end{array}$ & $\begin{array}{l}2270.25^{* * *} \\
(803.79)\end{array}$ & $\begin{array}{l}2353.40^{* * *} \\
(801.97)\end{array}$ \\
\hline Age squared & $\begin{array}{l}-41.92^{* * *} \\
(2.99)\end{array}$ & $\begin{array}{c}-29.44^{* * *} \\
(8.63)\end{array}$ & $\begin{array}{c}-29.68^{* * *} \\
(8.71)\end{array}$ & $\begin{array}{l}-29.56^{* * *} \\
(8.76)\end{array}$ \\
\hline State unemp rate & $\begin{array}{l}-675.83^{* * *} \\
(164.76)\end{array}$ & $\begin{array}{l}-283.45 \\
(318.38)\end{array}$ & $\begin{array}{l}-232.99 \\
(311.82)\end{array}$ & $\begin{array}{l}-295.83 \\
(319.34)\end{array}$ \\
\hline Unemp - 2 & & & $\begin{array}{l}1976.61^{* * *} \\
(618.17)\end{array}$ & $\begin{array}{l}1961.24^{* * *} \\
(618.47)\end{array}$ \\
\hline Unemp - 1 & & & $\begin{array}{l}3398.84^{\text {*** }} \\
(1160.11)\end{array}$ & $\begin{array}{l}3372.64^{* * *} \\
(1162.78)\end{array}$ \\
\hline Unemp +1 & & & $\begin{array}{l}-2333.41 \\
(1692.36)\end{array}$ & $\begin{array}{l}-2393.50 \\
(1691.71)\end{array}$ \\
\hline Unemp +2 & & & $\begin{array}{c}-682.17 \\
(1980.37)\end{array}$ & $\begin{array}{c}-766.74 \\
(1977.69)\end{array}$ \\
\hline Unemp +3 & & & $\begin{array}{c}180.24 \\
(2381.68)\end{array}$ & $\begin{array}{c}74.96 \\
(2380.67)\end{array}$ \\
\hline Unemp +4 & & & $\begin{array}{c}1016.06 \\
(2674.25)\end{array}$ & $\begin{array}{c}897.61 \\
(2673.10)\end{array}$ \\
\hline Unemp +5 & & & $\begin{array}{c}3685.93 \\
(2827.70)\end{array}$ & $\begin{array}{c}3584.10 \\
(2826.17)\end{array}$ \\
\hline Unemp +6 & & & $\begin{array}{c}4640.99 \\
(2976.98)\end{array}$ & $\begin{array}{c}4601.07 \\
(2974.30)\end{array}$ \\
\hline Observations & 74,577 & 14,794 & 14,794 & 14,794 \\
\hline Filing units & 9,749 & 14,794 & 1,984 & 1,984 \\
\hline
\end{tabular}

Each regression includes year and state dummy variables, a set of controls for lagged wage income, and filing unit fixed effects. Standard errors are clustered at the filing unit level. The dependent variable in column 1 is annual wage and salary income for the filing unit. The dependent variable in the remaining columns is individual-level wage income of the individual receiving UI income. 
Table 3: Decomposing Household-Level Wage Responses for Married Couples

\begin{tabular}{|c|c|c|c|c|}
\hline \multicolumn{5}{|c|}{ A. Either Spouse Can Be Unemployed } \\
\hline & $\begin{array}{l}\text { Household } \\
\text { Wages } \\
\text { (1) }\end{array}$ & $\begin{array}{c}\text { Wages, } \\
\text { Unemp Person } \\
(2)\end{array}$ & $\begin{array}{l}\text { Wages, } \\
\text { Spouse } \\
\text { (3) }\end{array}$ & $\begin{array}{c}\text { Spouse } \\
\text { Employed? } \\
\text { (4) }\end{array}$ \\
\hline Unemp & $\begin{array}{l}-3876.51^{* *} \\
(1955.30)\end{array}$ & $\begin{array}{l}-5852.89^{* * *} \\
(1665.98)\end{array}$ & $\begin{array}{c}1756.94 \\
(1175.93)\end{array}$ & $\begin{array}{c}1.33 \\
(1.74)\end{array}$ \\
\hline Unemp $\cdot$ MaxUI & $\begin{array}{c}-16.66^{* * *} \\
(5.65)\end{array}$ & $\begin{array}{c}-12.49^{* * *} \\
(4.83)\end{array}$ & $\begin{array}{l}-4.34 \\
(3.44)\end{array}$ & $\begin{array}{l}-0.0007 \\
(0.005)\end{array}$ \\
\hline Observations & 32,137 & & & \\
\hline Filing Units & 3,930 & & & \\
\hline \multicolumn{5}{|c|}{ B. Unemployment Spells of Husbands Only } \\
\hline & $\begin{array}{c}\text { Household } \\
\text { Wages }\end{array}$ & $\begin{array}{l}\text { Wages, } \\
\text { Husband }\end{array}$ & $\begin{array}{c}\text { Wages, } \\
\text { Wife }\end{array}$ & $\begin{array}{c}\text { Wife } \\
\text { Employed? }\end{array}$ \\
\hline Unemp & $\begin{array}{l}-5467.56^{* *} \\
(2579.98)\end{array}$ & $\begin{array}{l}-5283.50^{* *} \\
(2345.94)\end{array}$ & $\begin{array}{c}-282.46 \\
(1314.74)\end{array}$ & $\begin{array}{c}3.39 \\
(2.40)\end{array}$ \\
\hline Unemp $\cdot$ MaxUI & $\begin{array}{c}-15.45^{* *} \\
(7.57)\end{array}$ & $\begin{array}{c}-17.07^{* *} \\
(6.96)\end{array}$ & $\begin{array}{c}1.23 \\
(3.84)\end{array}$ & $\begin{array}{l}-0.005 \\
(0.006)\end{array}$ \\
\hline Observations & 20,118 & & & \\
\hline Filing Units & 2,436 & & & \\
\hline \multicolumn{5}{|c|}{ C. Unemployment Spells of Wives Only } \\
\hline & $\begin{array}{c}\text { Household } \\
\text { Wages }\end{array}$ & $\begin{array}{l}\text { Wages, } \\
\text { Wife }\end{array}$ & $\begin{array}{l}\text { Wages, } \\
\text { Husband }\end{array}$ & $\begin{array}{c}\text { Husband } \\
\text { Employed? }\end{array}$ \\
\hline Unemp & $\begin{array}{l}-2661.33 \\
(2881.63)\end{array}$ & $\begin{array}{l}-6920.59^{* * *} \\
(2,044.33)\end{array}$ & $\begin{array}{c}3918.85^{*} \\
(2246.60)\end{array}$ & $\begin{array}{l}-1.08 \\
(2.17)\end{array}$ \\
\hline Unemp $\cdot$ MaxUI & $\begin{array}{r}-14.84^{*} \\
(8.02)\end{array}$ & $\begin{array}{l}-4.45 \\
(5.34)\end{array}$ & $\begin{array}{r}-10.49 \\
(6.60)\end{array}$ & $\begin{array}{c}0.005 \\
(0.006)\end{array}$ \\
\hline Observations & 12,019 & & & \\
\hline Filing Units & 1,494 & & & \\
\hline
\end{tabular}

Each regression includes year and state dummy variables, a set of controls for lagged wage income of each spouse, and filing unit fixed effects. The sample is restricted to those who are married filing jointly in the first year of UI receipt. Cases where both spouses receive UI income are dropped. Standard errors are clustered at the filing unit level. 
Table 4: Fixed Effect Regression Results, Non-Wage Income

\begin{tabular}{|c|c|c|c|c|c|}
\hline & $\begin{array}{l}\text { Non-Wage } \\
\text { Income } \\
(1)\end{array}$ & $\begin{array}{c}\text { Capital } \\
\text { Gains } \\
(2) \\
\end{array}$ & $\begin{array}{c}\text { Equity } \\
\text { Sale } \\
(3) \\
\end{array}$ & $\begin{array}{c}\text { Retirement } \\
\text { Penalty } \\
(4) \\
\end{array}$ & $\begin{array}{c}\text { Other } \\
\text { Penalty } \\
(5) \\
\end{array}$ \\
\hline Unemp & $\begin{array}{l}3406.47^{* * *} \\
(1215.42)\end{array}$ & $\begin{array}{c}2183.84^{*} \\
(1133.29)\end{array}$ & $\begin{array}{l}12254.20^{*} \\
(7185.41)\end{array}$ & $\begin{array}{c}36.15 \\
(28.03)\end{array}$ & $\begin{array}{l}3.82^{* *} \\
(1.95)\end{array}$ \\
\hline Unemp $\cdot$ MaxUI & $\begin{array}{l}-5.37 \\
(3.50)\end{array}$ & $\begin{array}{l}-5.23 \\
(3.22)\end{array}$ & $\begin{array}{l}-22.61 \\
(16.91)\end{array}$ & $\begin{array}{c}0.12 \\
(0.08)\end{array}$ & $\begin{array}{l}-0.01^{*} \\
(0.006)\end{array}$ \\
\hline MaxUI & $\begin{array}{l}21.91^{* * *} \\
(5.50)\end{array}$ & $\begin{array}{l}10.31 \\
(6.77)\end{array}$ & $\begin{array}{c}81.71 \\
(63.00)\end{array}$ & $\begin{array}{l}-0.02 \\
(0.09)\end{array}$ & $\begin{array}{c}0.01^{*} \\
(0.005)\end{array}$ \\
\hline Married & $\begin{array}{c}-1069.93^{* *} \\
(457.32)\end{array}$ & $\begin{array}{c}273.81 \\
(283.85)\end{array}$ & $\begin{array}{c}2431.49 \\
(3557.47)\end{array}$ & $\begin{array}{c}11.59 \\
(10.20)\end{array}$ & $\begin{array}{c}0.43 \\
(0.44)\end{array}$ \\
\hline Children & $\begin{array}{l}1143.01^{* * *} \\
(176.99)\end{array}$ & $\begin{array}{l}152.27^{*} \\
(88.67)\end{array}$ & $\begin{array}{c}3314.57 \\
(2706.93)\end{array}$ & $\begin{array}{c}3.35 \\
(3.92)\end{array}$ & $\begin{array}{l}-0.12 \\
(0.19)\end{array}$ \\
\hline Age (primary) & $\begin{array}{l}-742.31^{* * *} \\
(275.80)\end{array}$ & $\begin{array}{c}-97.78 \\
(253.57)\end{array}$ & $\begin{array}{c}1004.98 \\
(1304.04)\end{array}$ & $\begin{array}{c}1.69 \\
(4.90)\end{array}$ & $\begin{array}{c}0.02 \\
(0.26)\end{array}$ \\
\hline Age squared & $\begin{array}{l}26.45^{* * *} \\
(3.02)\end{array}$ & $\begin{array}{c}0.93 \\
(2.17)\end{array}$ & $\begin{array}{l}-31.51^{*} \\
(17.01)\end{array}$ & $\begin{array}{l}-0.01 \\
(0.05)\end{array}$ & $\begin{array}{l}-0.004 \\
(0.004)\end{array}$ \\
\hline State unemp rate & $\begin{array}{l}-463.03 \\
(292.74)\end{array}$ & $\begin{array}{l}-146.94 \\
(171.43)\end{array}$ & $\begin{array}{c}1638.30 \\
(1596.30)\end{array}$ & $\begin{array}{c}2.52 \\
(3.27)\end{array}$ & $\begin{array}{c}0.17 \\
(0.23)\end{array}$ \\
\hline Fed tax rate & $\begin{array}{l}24.93^{* *} \\
(10.05)\end{array}$ & $\begin{array}{l}54.44^{* * *} \\
(8.54)\end{array}$ & $\begin{array}{c}65.25 \\
(41.66)\end{array}$ & $\begin{array}{l}0.83^{* * *} \\
(0.17)\end{array}$ & $\begin{array}{l}-0.07 \\
(0.07)\end{array}$ \\
\hline State tax rate & $\begin{array}{c}28.93 \\
(63.27)\end{array}$ & $\begin{array}{c}48.62 \\
(37.64)\end{array}$ & $\begin{array}{c}110.78 \\
(151.31)\end{array}$ & $\begin{array}{l}-0.65 \\
(0.83)\end{array}$ & $\begin{array}{c}0.05 \\
(0.11)\end{array}$ \\
\hline $\begin{array}{l}\text { Observations } \\
\text { Filing Units }\end{array}$ & $\begin{array}{l}74,577 \\
9,749\end{array}$ & & & & \\
\hline \% With Income Type & 23.9 & 10.5 & 8.6 & 12.4 & 0.6 \\
\hline
\end{tabular}

Each regression includes year and state dummy variables, a set of controls for lagged wage income, and filing unit fixed effects. Standard errors are clustered at the filing unit level. 
Table 5: Heterogeneity in Non-Wage Income Responses

\begin{tabular}{|c|c|c|c|c|c|}
\hline & $\begin{array}{l}\text { Non-Wage } \\
\text { Income } \\
(1)\end{array}$ & $\begin{array}{c}\text { Capital } \\
\text { Gains } \\
(2)\end{array}$ & $\begin{array}{c}\text { Equity } \\
\text { Sale } \\
(3)\end{array}$ & $\begin{array}{c}\text { Retirement } \\
\text { Penalty } \\
(4)\end{array}$ & $\begin{array}{c}\text { Other } \\
\text { Penalty } \\
(5)\end{array}$ \\
\hline \multicolumn{6}{|c|}{ A. By Presence of Equity-Based Income Prior to Unemployment } \\
\hline \multicolumn{6}{|c|}{ Equity Income Present Prior to UI Receipt, $N=20,227$} \\
\hline Unemp & & $\begin{array}{c}7472.97^{*} \\
(4065.68)\end{array}$ & $\begin{array}{c}43721.17 \\
(26815.33)\end{array}$ & & \\
\hline Unemp $\cdot$ MaxUI & & $\begin{array}{l}-18.20^{*} \\
(10.97)\end{array}$ & $\begin{array}{l}-80.03 \\
(58.58)\end{array}$ & & \\
\hline \multicolumn{6}{|c|}{ No Equity Income Prior to UI Receipt, $N=54,350$} \\
\hline Unemp & & $\begin{array}{c}21.11 \\
(137.55)\end{array}$ & $\begin{array}{c}519.22 \\
(1413.36)\end{array}$ & & \\
\hline \multicolumn{2}{|l|}{ Unemp $\cdot$ MaxUI } & $\begin{array}{c}0.16 \\
(0.40)\end{array}$ & $\begin{array}{l}-0.55 \\
(5.06)\end{array}$ & & \\
\hline \multicolumn{6}{|l|}{ B. By Age } \\
\hline \multicolumn{6}{|c|}{ Younger Cohort, $N=37,458$} \\
\hline Unemp & $\begin{array}{c}1628.81 \\
(1571.54)\end{array}$ & $\begin{array}{c}2371.41 \\
(1839.70)\end{array}$ & $\begin{array}{c}14396.04 \\
(10656.40)\end{array}$ & $\begin{array}{l}-11.42 \\
(33.41)\end{array}$ & $\begin{array}{l}1.35 \\
(1.23)\end{array}$ \\
\hline Unemp $\cdot$ MaxUI & $\begin{array}{l}-2.22 \\
(4.79)\end{array}$ & $\begin{array}{l}-7.39 \\
(5.34)\end{array}$ & $\begin{array}{l}-20.55 \\
(23.93)\end{array}$ & $\begin{array}{c}0.25^{* *} \\
(0.10)\end{array}$ & $\begin{array}{l}-0.004 \\
(0.003)\end{array}$ \\
\hline \multicolumn{6}{|c|}{ Older Cohort, $N=37,119$} \\
\hline Unemp & $\begin{array}{l}4950.06^{* * *} \\
(1797.08)\end{array}$ & $\begin{array}{c}1909.94 \\
(1353.84)\end{array}$ & $\begin{array}{c}10829.78 \\
(10559.77)\end{array}$ & $\begin{array}{c}81.38^{*} \\
(44.50)\end{array}$ & $\begin{array}{c}6.31^{*} \\
(3.73)\end{array}$ \\
\hline Unemp $\cdot$ MaxUI & $\begin{array}{l}-7.79 \\
(4.98)\end{array}$ & $\begin{array}{l}-2.85 \\
(3.65)\end{array}$ & $\begin{array}{l}-27.22 \\
(26.16)\end{array}$ & $\begin{array}{l}0.0004 \\
(0.13)\end{array}$ & $\begin{array}{l}-0.018 \\
(0.011)\end{array}$ \\
\hline \multicolumn{6}{|c|}{ C. By Homeowner Status } \\
\hline \multicolumn{6}{|c|}{ No Mortgage Interest or Property Tax Deduction, $N=42,592$} \\
\hline Unemp & $\begin{array}{l}1302.21^{* * * *} \\
(431.76)\end{array}$ & $\begin{array}{l}-112.33 \\
(146.26)\end{array}$ & $\begin{array}{c}-458.74 \\
(2906.16)\end{array}$ & $\begin{array}{c}34.38^{*} \\
(18.69)\end{array}$ & $\begin{array}{c}4.92 \\
(3.25)\end{array}$ \\
\hline Unemp $\cdot$ MaxUI & $\begin{array}{l}-1.66 \\
(1.20)\end{array}$ & $\begin{array}{c}0.41 \\
(0.42)\end{array}$ & $\begin{array}{c}3.59 \\
(8.22)\end{array}$ & $\begin{array}{c}0.04 \\
(0.05)\end{array}$ & $\begin{array}{l}-0.01 \\
(0.01)\end{array}$ \\
\hline \multicolumn{6}{|c|}{ Mortgage Interest or Property Tax Deduction, $N=31,985$} \\
\hline Unemp & $\begin{array}{l}5582.30^{* *} \\
(2661.20)\end{array}$ & $\begin{array}{l}6319.74^{* *} \\
(3167.44)\end{array}$ & $\begin{array}{c}29551.35^{*} \\
(17396.87)\end{array}$ & $\begin{array}{c}57.59 \\
(67.22)\end{array}$ & $\begin{array}{l}-0.22 \\
(2.43)\end{array}$ \\
\hline Unemp $\cdot$ MaxUI & $\begin{array}{l}-8.63 \\
(7.14)\end{array}$ & $\begin{array}{c}-15.32^{*} \\
(8.87)\end{array}$ & $\begin{array}{l}-59.39 \\
(38.89)\end{array}$ & $\begin{array}{c}0.19 \\
(0.19)\end{array}$ & $\begin{array}{l}-0.001 \\
(0.006)\end{array}$ \\
\hline
\end{tabular}

In panel A, filing units are classified as having equity income prior to UI receipt if they realized capital gains, reported income from selling equity, or received dividend income in any year between 1999 and the first year in which they received UI income. Panel B groups filing units on the basis of the age of the primary filer in 1999. When the primary filer is 37 or younger in 1999, the filing unit is placed in the younger cohort. In panel $\mathrm{C}$, a filing unit is considered to own a home if at any point the filing unit pays mortgage interest (as shown on Schedule A or Form 1098) or deducts property tax (as shown on Schedule A). 